\title{
Optimize the Time and Network on the Distribution of Tempe Industry by Using the Approach of the Assignment and Networking
}

\author{
Gina Agnia ${ }^{1}$, Dene Herwanto ${ }^{2}$, Ica Hoerunisa ${ }^{3}$, Billy Nugraha ${ }^{4}$, Rianita Puspa Sari ${ }^{5}$ \\ 1, 2,3,4,5 Industrial Engineering Department, Universitas Singaperbangsa Karawang, Karawang \\ *Koresponden email: ginagnia99@gmail.com
}

Diterima: 30 Desember 2020

Disetujui: 16 Februari 2021

\begin{abstract}
The problems that occur in the soybean tempe home industry are the competition in the market sector and unstable prices. The purpose of this study is to determine the assignment of employees in performing their works and to distribute them to each destination with the shortest distance. The research method used is assignment, networking using the assistance of the operations management software program quantitative methods (POM-QM) for windows. The data used are the primary data conducted in a preliminary study. In addition, data collection techniques are carried out in several ways, namely interviews, observation and schedule recording. The finding provides optimal results for all four employees based on suitable jobs. Each employee is employee 1 with a type of laundering taking 17 minutes. Employees 2 with a kneading type of work taking 35 minutes. Eemployees 3 with wrapping job type taking 10 minutes. Meanwhile, eemployees 4 is breawing taking 15 minutes. In addition, the distribution of tempe to the destination point with the shortest route produces a distance of $76 \mathrm{~km}$.
\end{abstract}

Keywords:, assignment, home industry, networking, tempe, POM-QM.

\begin{abstract}
Abstrak
Permasalahan yang terjadi di home industry pembuat tempe kedelai adalah persaingan di sektor pasar dan harga kacang kedelai yang tidak stabil. Tujuan penelitian ini untuk mengetahui penugasan pegawai dengan pekerjaannya dan pendistribusian ke setiap titik tujuan dengan jarak terpendek. Metode penelitian yang digunakan adalah assignment, networking dan menggunakan bantuan software program operations management - quantitative methods (POM-QM) for windows. Data yang digunakan adalah data primer yang dilakukan dalam studi pendahuluan. Selain itu teknik pengumpulan data dilakukan dengan beberapa cara, yaitu wawancara, observasi dan pencatatan jadwal. Hasil dari penelitian ini mendapatkan hasil yang optimal bagi ke empat pegawai berdasarkan pekerjaan yang cocok. Masing-masing pegawai yaitu pegawai 1 dengan jenis pekerjaaan pencucian dan membutuhkan waktu 17 menit. Pegawai 2 dengan jenis pekerjaan peremasan dan membutuhkan waktu 35 menit. Pegawai 3 dengan jenis pekerjaan pembungkusan dan membutuhkan waktu 10 menit. Sedangkan Pegawai 4 dengan jenis pekerjaan peragian dan membutuhkan waktu 15 menit. Selain itu pendistribusian tempe ke titik tujuan dengan jalur terpendek menghasilkan jarak $76 \mathrm{~km}$.
\end{abstract}

Kata Kunci: industri rumah tangga, penugasan, jaringan, tempe, POM-QM.

\section{Introduction}

The optimal allocation productive resources seems to be a challenge that is often encountered in the business word and home industry productive resources [1]. It has a level of efficiency that is distinct to various jobs-different [2]. The assignment problem is a setting on the employee to carry out the task [3]. Thus the cost of or the time used for the implementation can be minimized. Customer satisfaction is the aspects that need to be considered [4]. To be able to maximize-the determination of the prices and keep the quality of the goods [5]. Then the distribution of goods should be effective and efficient. The manufacturers need to make a visit to destination place to store the goods [6]. They should be able to choose an appropriate method in the distribution of goods. This research was conducted in the Home Industry producing tempe, located in Karawang.

One of home industries producing tempe, has several production activities, such as: washing, kneading, fermentation and packaging. The problems commonly occurred in the home industry tempe is optimizing the working time of employees in accordance with his job [7]. In addition, it also relates to the distribution of tempeh to some destination places by considering effectiveness and the efficiency of the distance traveled [8]. Renewal in this research used the help of software program operations management - quatitative methods (POM-QM) for windows. This Software is used as an alternative in solving the 
problem of maximum and minimum [9]. In addition, it is also to determine the assignment of employees working performance. Assisted by the software, the problems in the assignment of employees can be completed more quickly and obtain accurate results [10].

The purpose of this study is to determine the assignment of the employees' working performance to their job and distribution to any point of destination with the shortest distance. The research method used is the assignment, networking and using the academics help of software programs operations management - quantitative methods (POM-QM) for windows.

The Method of Linear Programming

The method of linear programming is the mathematical model formulation of the problem [9]. The objective function to describe the objective/goal in the problems of linear programming. In order to facilitate the discussion of the linear model programming, use the symbols below:

$i=$ A lot of workers $\mathrm{i}=1,2,3, \ldots, \mathrm{m}$

$j \quad=$ Many types of products $\mathrm{j}=1,2,3, \ldots, \mathrm{n}$

$h_{i}=$ Workers' availability $\mathrm{i}=1,2,3, \ldots, \mathrm{m}$

$a_{i}=$ Workers who are working/producing 1 unit of product

$x_{j}=$ The level of activity

$C_{i}=$ The cost of operation

It is a problem in linear programming to become a function of the limitation, use the formula below:

$$
\text { Min } \mathrm{Z}=c_{1} x_{1}+a_{1} x_{2}+\ldots+c_{1 j} x_{j}+\ldots+c_{1 n} x_{n}
$$

The next problem in linear programming becomes a function of the limitation, use the formula below:

$$
\begin{gathered}
a_{1} x_{1}+a_{1} x_{2}+\ldots+a_{1 j} x_{j}+a_{1 n} x_{n} \leq h_{1} \\
a_{2} x_{1}+a_{2} x_{2}+\ldots+a_{2 j} x_{j}+a_{2 n} x_{n} \leq h_{2} \\
\vdots \\
a_{i 1} x_{1}+a_{i 2} x_{2}+\ldots+a_{i} x_{j}+a_{i} x_{n} \leq h_{i} \\
\vdots \\
a_{m 1} x_{1}+a_{m 2} x_{2}+\ldots+a_{m} X_{j}+a_{m} x_{n} \leq h_{m} \\
x_{j} \geq O_{j}=1,2,3, \ldots, \mathrm{n}
\end{gathered}
$$

\section{The Method of Assignment}

The method of assignment (hungarian) is a method to modify the rows and columns in the matrix of effectiveness, with a zero component of a single object in each row or column can be selected as the allocation assignment [11]. The preparation of the assignment problem with a minimization as follows:

1. Draw up a table of tasks.

2. Do the subtraction row by selecting the smallest item of each line and subtracts this to every number in that row.

3. If the results obtained 0 in each column, then it can be processed to the next stage. But if not, then the smallest number in the column that does not have a 0 must be subtracted to each number in the column of that row.

4. Then make assignment of the minimum by forming the line on the value of that has a lot of 0 .

\section{The Method of Networking}

Model a special case of the model of networking is the number $\mathrm{M}$ of the source that is assigned. Through a number of objects $\mathrm{N}$ (one source to one destination), so it can be subject to a minimum fee total [5]. Usually what is meant by source is the work (or the employee). Whereas the objective is a machine. So, in this case there are employees (m) assigned to the machine (n). If employee I (I = $1,2, \ldots, \mathrm{m})$, assigned to machine $\mathrm{j}(\mathrm{j}=1,2, \ldots, \mathrm{n})$ will appear cost of the assignment of the $\mathrm{C}_{\mathrm{ij}}$.

Software POM-QM for Windows

One of the software that can help workmanship assignment is POM for windows. According to Weiss, 2013 the first version of the software is shaped DOS published in 1989 as PC-POM. The next version of the DOS was given the name of AB:POM. The windows version first, namely QM for windows (version 1.0), distributed in the summer of 1996 is a separate program but still similar. DS for windows composed of modules POM and QM with the manual was first distributed in 1997. The second version of these three programs made for windows 95 and distributed in the fall of 1999 [12]. Currently developing the third version, namely POM-QM for windows. 


\section{Literature Review}

Some of findings in the previous research employed the method of assignment or hungarian. It is as a parameter in the research conducted, as follows: The research conducted by D. T. Prataman and H. S. Kurniawan: Problems in the study that the assignment of the operators in each work station is not in accordance with the skills possessed by each operator, the assignment problem is a special problem of linear programming, which is part of applied mathematics that can be used to solve the problem of allocation of limited resources optimally. The implementation of the concept assignment of Hungarian method can minimize the production time by 8 minutes compared to the actual time of manufacturing process of the fence before [13]. The research conducted by Amalia Ayu Lailasari: the test Results obtained by statistical differences between the methods, the team with the functional method obtained $p$ value of 0.001 , indicating there is a significant difference between the average score of patient satisfaction in the inpatient unit that implements the method of the assignment of the team and the space applying the method of the assignment of the functional based on the dimensions of reliability, responsiveness, assurance, appearance and empathy [14]. Additionally, the research conducted by Dhion Meitreya Vidhiasi, show that although some students find difficulty in operating the google classroom, they are eager to learn through service and through the method of the assignment [15]. Moreover, the research conducted by Diang Goddess Tamimi, Ika Purnamasari and Wasono, it is found that the total cost for one purpose only consider the operation cost is Rp.2.950.000 as 63 days [16]. Lastly, the research conducted by Slamet Basuki: The method of assignment in accordance with the pandemic of Covid-19. This is to minimize the shipping cost [17].

Meanwhile some other studies applying the method of assignment or hungarian as follows, the research conducted by G. N. P. Suwandira, Retno Indryani and Ida Ayu Rai Widhiawati (year), the total cost is Rp.29.456.132.296,00, while the total cost of the minimum from in the field obtained at a cost of Rp.32.347.308.872,00. Therefore, with a model of the assignment of the obtained cost savings of Rp.2.891.176.576,00 [18]. The research conducted by Sutejo: this article provides guidelines on how should the assignment is constructed in accordance with the views of the constructivist [19]. The research conducted by Yuta Ardianti Putri, Zeny Fatimah Hunusalela and Elfitria Wiratmani, in which the assignment based on the processing time will be pressing time so that repetation is completed in accordance with the time specified. The placement of workers based on the proportion of errors is done by placing group 1 to the work product big C'frut, group 2 for the work product of a national milk, group 3 for workmanship bintang radler, group 4 to the work product KPBS canning [20]. The research conducted by Evan Nugraha and Rini Mulyani Sari: test results of the optimum from the study then the method of VAM and the method of assignment can be applied on the company making the bread [21]. The research conducted by Helena Sitorus, Ratna Suminar, and Arohman Dwi Santoso: the Results of the findings of the study show that production Target (sales target). To get the maximum profit is to produce dump truck as many as 73 units, the subframe 120 units, tilting 29 units, and tank truck 33 units. This solution gives rise to a gain of $0.9 \%$ [22]. The difference from the previous research is found by he retry on the application POM-QM. The results obtained are the results of the calculation are the same as the manual way. This is to prove that the results of the manual calculation is right. In addition, refer to utilize the development of science and technology in the present time to obtain an accurate result.

\section{Material and Methods \\ Preliminary Studies}

A preliminary study was conducted to determine how the groove until the results. Preliminary studies are divided into two phases, namely the literature study and the field. The study of literature is done by the process of review the results of the same study (using the method of assignment, and networking). While the field study was conducted in the Gemanis, RT/RW 002/032, Village of Karawang Wetan, Kecamatan Karawang Timur - 41314, Karawang Regency.

\section{Data Collection Techniques}

The data collection of this research was divided into two parts, namely primary and secondary data. Primary Data refers to the activities of the production process of each employee. Meanwhile the secondary data relates to the supporting data in this research based on a literature study.

Analysis

In the analysis review assignments based on the calculation of the standard time and also the proportion of his guilt. In addition, it carried out a comparative analysis of the assignment based on the two factors in the tests. 


\section{Conclusion and Suggestions}

As a result of the research that has been done, made a conclusion as a form of hypothesis in this study. While the advice given to the home industry of tempe to improve the system of assignment at this time.

The Procedure Flow Of Research

In this section describe the procedure flow of the research conducted. as in Figure 1. below:

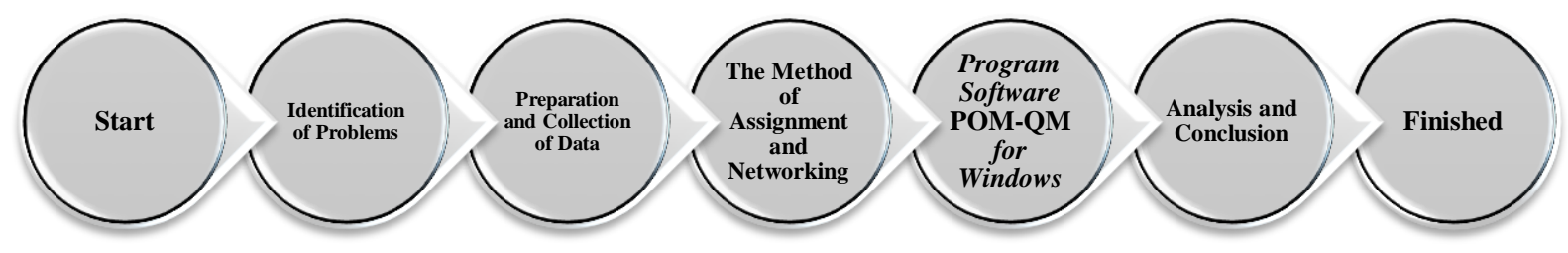

Figure 1. The procedure flow of research Source: (Research Processing Results, 2020)

\section{Results and Discussion}

\section{The Method of Assignment}

The method of assignment used in this research to obtain optimal results from the assignment of the employee. Here are the results of observations of the assignment of the employee in Table 1.

Table 1. The results of observations of the assignment employee

\begin{tabular}{lcccc}
\hline \multirow{2}{*}{ Type of Assignment } & \multicolumn{4}{c}{ Number of Employees } \\
& Employee 1 & Employee 2 & Employee 3 & Employee 4 \\
\hline Laundering & 17 & 25 & 15 & 15 \\
Kneading & 40 & 35 & 42 & 40 \\
Brewing & 15 & 8 & 12 & 10 \\
Wrapping & 23 & 15 & 15 & 20 \\
\hline
\end{tabular}

Source: Home industry tempe, 2020

Here are some stages in the processing using the method of assignment, as follows:

1. Stage 1 : Define the Problem

The Objective Function:

Minimize $\mathrm{Z}=$

$$
\sum_{i}^{4}=1 \sum_{j}^{4}=1 t_{i j} X_{i j}
$$

With $\mathrm{Z}$ is the total time of manufacture of the goods and $\mathrm{t}_{\mathrm{ij}}$ is the time required by the employee (i) to complete the assignment ( $\mathrm{j}$ ) and $\mathrm{X}_{\mathrm{ij}}$ is the assignment of an employee (i) to the assignment (j). That can be formulated into programming linear as follows:

Minimaze $\mathrm{Z}=$

$$
\begin{aligned}
& 15 x_{11}+25 x_{12}+15 x_{13}+15 x_{14}+40 x_{21}+35 x_{22}+42 x_{23}+40 x_{23}+ \\
& 40 x_{24}+15 x_{31}+8 x_{32}+12 x_{33}+10 x_{34}+23 x_{41}+15 x_{42}+15 x_{43}+ \\
& 20 x_{44}
\end{aligned}
$$

The Constraint function:

Constraint Employees =

2. Stage 2 : Model Development

$$
\begin{aligned}
& x_{11}+x_{21}+x_{31}+x_{41}=1 \\
& x_{12}+x_{22}+x_{32}+x_{42}=1 \\
& x_{13}+x_{23}+x_{33}+x_{43}=1 \\
& x_{14}+x_{24}+x_{34}+x_{44}=1 \\
& \text { The Constrain Assigment }=x_{11}+x_{21}+x_{31}+x_{41}=1 \\
& x_{12}+x_{22}+x_{32}+x_{42}=1 \\
& x_{13}+x_{23}+x_{33}+x_{43}=1 \\
& x_{14}+x_{24}+x_{34}+x_{44}=1
\end{aligned}
$$

Here are the results matrix and the model of the method of assignment in this study on Table 2. and Table 3. 
Table 2. Matrix assignment

\begin{tabular}{|c|c|c|c|c|c|c|c|c|}
\hline Type of & \multicolumn{7}{|c|}{ Employee } & \multirow{2}{*}{ Capacity } \\
\hline Assignment & & 1 & & 2 & 3 & & & \\
\hline 1 & $X_{11}$ & $C_{11}$ & $X_{12}$ & $C_{12}$ & $\ldots$ & $X_{1 \mathrm{~m}}$ & $C_{1 \mathrm{n}}$ & 1 \\
\hline 2 & $X_{21}$ & $C_{21}$ & $\mathrm{X}_{22}$ & $C_{22}$ & $\ldots$ & $X_{2 \mathrm{~m}}$ & $C_{2 \mathrm{n}}$ & 1 \\
\hline$\vdots$ & & $\vdots$ & & $\vdots$ & $\vdots$ & & & $\vdots$ \\
\hline 3 & $X_{\mathrm{m} 1}$ & $C_{\mathrm{m} 1}$ & $\mathrm{X}_{\mathrm{m} 2}$ & $C_{\mathrm{m} 2}$ & $\ldots$ & $X_{\mathrm{mn}}$ & $C_{\mathrm{mn}}$ & 1 \\
\hline Capacity & & 1 & & 1 & $\ldots$ & & & \\
\hline
\end{tabular}

Source: Research processing results, 2020

Table 3. Model assignment

\begin{tabular}{lcccc}
\hline \multirow{2}{*}{ Type of Assignment } & \multicolumn{4}{c}{ Number of Employees } \\
& Employee 1 & Employee 2 & Employee 3 & Employee 4 \\
\hline Laundering & 17 & 25 & 15 & 15 \\
Kneading & 40 & 35 & 42 & 40 \\
Brewing & 15 & 8 & 12 & 10 \\
Wrapping & 23 & 15 & 15 & 20 \\
\hline
\end{tabular}

Source: Research processing results, 2020

3. Stage 3 : Solving the Model

To complete the assignment problem, in order to obtain a settlement that can optimally use the following steps:

a. Specify the entry of the smallest of each line in Table 3. at the top, then subtracting all entries in that row with the entry of the smallest. As in Table 4.

Table 4. The Determination of the entry of the smallest of each line

\begin{tabular}{lcccc}
\hline \multirow{2}{*}{ Type of Assignment } & \multicolumn{4}{c}{ Number of Employees } \\
& Employee 1 & Employee 2 & Employee 3 & Employee 4 \\
\hline Laundering & 17 & 25 & 15 & 15 \\
Kneading & 40 & 35 & 42 & 40 \\
\hline \multirow{2}{*}{ Type of Assignment } & Employee 1 & Employee 2 & Employee 3 & Employee 4 \\
& 15 & 8 & 12 & 10 \\
Brewing & 23 & 15 & 15 & 20 \\
Wrapping & \multicolumn{4}{c}{ Source: Research processing results, 2020 }
\end{tabular}

All entries on the first line subtracted by 15 and subtracted 35 on the second line. Next deductible 8 on the third line and the deductible 15 on the fourth line. To get the results as in Table 5.

Table 5. The results after deducting the smallest element

\begin{tabular}{lcccc}
\hline \multirow{2}{*}{ Type of Assignment } & \multicolumn{4}{c}{ Number of Employees } \\
& Employee 1 & Employee 2 & Employee 3 & Employee 4 \\
\hline Laundering & 17 & 25 & 15 & 0 \\
Kneading & 40 & 0 & 42 & 40 \\
Brewing & 15 & 0 & 12 & 10 \\
Wrapping & 23 & 15 & 0 & 20 \\
\hline
\end{tabular}

Source: Research processing results, 2020

b. Check every column with the entry of 0 . Because colums two, three, four and five and seven contains the entry 0 . Therefore, it needs to be deducted 2 entry. As in Table 6. 
Table 6. The result after the first column of the deductible by the smallest element

\begin{tabular}{lcccc}
\hline \multirow{2}{*}{ Type of Assignment } & \multicolumn{4}{c}{ Number of Employees } \\
& Employee 1 & Employee 2 & Employee 3 & Employee 4 \\
\hline Laundering & 0 & 10 & 0 & 0 \\
Kneading & 3 & 0 & 7 & 5 \\
Brewing & 5 & 0 & 4 & 2 \\
Wrapping & 6 & 0 & 0 & 5 \\
\hline
\end{tabular}

Source: Research processing results, 2020

c. Closing of all values 0 by using vertical or horizontal lines to a minimum. As in Table 7.

Table 7. Closing all the values 0

\begin{tabular}{lcccc}
\hline \multirow{2}{*}{ Type of Assignment } & \multicolumn{4}{c}{ Number of Employee } \\
& Employee 1 & Employee 2 & Employee 3 & Employee 4 \\
\hline Laundering & 0 & 1 & 0 & 0 \\
Kneading & 3 & $\$$ & 4 & 5 \\
Brewing & 5 & Source: Research processing results, 2020 & 0 & 5 \\
Wrapping & \multicolumn{2}{c}{}
\end{tabular}

d. Because the minimum number of lines used in step $\mathrm{c}$ is three lines. Then the assignment is not optimal and should be done in the following step.

e. Specify the entry of the smallest of the entries which are not closed lines. Then all entries that are not closed line deductible with the entry of the smallest. But the entry that is enclosed by two rows added with entries smallest. Then carried out the closing of all values 0 by using the lines to a minimum. As in Table 8. and Table 9.

Table 8. The reduction in entries that are not closed line

\begin{tabular}{lcccc}
\hline \multirow{2}{*}{ Type of Assignment } & \multicolumn{4}{c}{ Number of Employees } \\
& Employee 1 & Employee 2 & Employee 3 & Employee 4 \\
\hline Laundering & 0 & 12 & 0 & 0 \\
Kneading & 1 & 0 & 5 & 3 \\
Brewing & 3 & 0 & 2 & 0 \\
Wrapping & 6 & 2 & 0 & 5 \\
\hline
\end{tabular}

Source: Research processing results, 2020

Table 9. The addition of the entry that closed the two lines

\begin{tabular}{lcccc}
\hline \multirow{2}{*}{ Type of Assignment } & \multicolumn{4}{c}{ Number of Employees } \\
& Employee 1 & Employee 2 & Employee 3 & Employee 4 \\
\hline Laundering & 0 & 0 & 0 & 0 \\
Kneading & 1 & 0 & 2 & 3 \\
Brewing & 3 & 2 & 0 & 5 \\
Wrapping & 6 & Source: Research processing results, 2020
\end{tabular}

f. The matrix in step 5 shows that the number of lines that cover all the entry 0 is already equal to the number of rows or columns. Therefore the determination of the assignment has to be done. At the start of the row or column that has only one value 0 . As in Table $\mathbf{1 0 .}$

Table 10. The results of the optimal solution

\begin{tabular}{lcccc}
\hline \multirow{2}{*}{ Type of Assignmeny } & \multicolumn{4}{c}{ Number of Employee } \\
& Employee 1 & Employee 2 & Employee 3 & Employee 4 \\
\hline Laundering & 0 & 12 & 0 & 0 \\
Kneading & 1 & 0 & 5 & 3 \\
Brewing & 3 & 0 & 2 & 0 \\
Wrapping & 6 & 2 & 0 & 5 \\
\hline
\end{tabular}


4. Stage 4 : Testing the Validity of the Model

The Solutions or Decision:

$x_{11}=x_{22}=x_{34}=x_{43}=1$

By adjusting the variable results of the decision $\left(\mathrm{x}_{\mathrm{ij}}\right)$. The obtained total time of optimum (minimum) required for the manufacture of tempe are as follows:

$$
\begin{aligned}
& \mathrm{Z}=\sum_{i}^{4}=1 \sum_{j}^{4}=1 t_{i j} X_{i j} \\
& \mathrm{Z}=17 x_{11}+35 x_{22}+10 x_{34}+15 x_{43} \\
& \mathrm{Z}=17(1)+35(1)+10(1)+15(1) \\
& \mathrm{Z}=77 \text { Minute }
\end{aligned}
$$

5. Stage 5 : Implementation the Final Result

The setting of the assignment to method assignment (hungarian) obtained as in Table 11.

Table 11. Setting the assignment and the total time of manufacture of tempe

\begin{tabular}{clc}
\hline Number of Employees & Type of Assignment & Times (Minute) \\
\hline Employee 1 & Laundering & 17 \\
Employee 2 & Kneading & 35 \\
Employee 3 & Wrapping & 10 \\
Employee 4 & Brewing & 15 \\
\hline & Total
\end{tabular}

\section{The Method of Networking}

The method of networking used in this research to obtain optimal results from the distribution of tempe. Here are the results of observations of the distribution of tempe in Table 12.

Table 12. The results of the observation of the distribution of Tempe

\begin{tabular}{lcc}
\hline \multicolumn{1}{c}{ The Setting Point to a Destination } & Point & Distance $(\mathrm{km})$ \\
\hline Home Industry Tempe - Johar Market & $1-2$ & 2 \\
Home Industry Tempe - Baru Karawang Market & $1-3$ & 4 \\
Home Industry Tempe - Telagasari Market & $1-4$ & 10 \\
Johar Market - Baru Karawang Market & $2-3$ & 3 \\
Johar Market - Bojong Market & $2-5$ & 8 \\
Johar Market - Kaligandu Market & $2-6$ & 18 \\
Johar Market - Rengasdengklok Market & $2-7$ & 22 \\
Baru Karawang Market - Bojong Market & $3-5$ & 6 \\
Telagasari Market - Bojong Market & $4-5$ & 16 \\
Telagasari Market - Rengasdengklok Market & $4-7$ & 23 \\
Bojong Market - Kaligandu Market & $5-6$ & 20 \\
Bojong Market - Rengasdengklok Market & $5-7$ & 17 \\
\hline
\end{tabular}

Source: Home Industry Tempe, 2020

1. Stage 1 : Define the Problem

Function Purpose: To build a tree spanning a minimum of (minimum spanning tree) in the distribution of tempe. Function Constraints : As in Table 13.

Table 13. Data point and the distance

\begin{tabular}{ccc}
\hline Side & Point & Distance $(\mathrm{km})$ \\
\hline$x_{1}$ & $1-2$ & 2 \\
$x_{2}$ & $1-3$ & 4 \\
$x_{3}$ & $1-4$ & 10 \\
$x_{4}$ & $2-3$ & 3 \\
$x_{5}$ & $2-5$ & 8 \\
$x_{6}$ & $2-6$ & 18 \\
$x_{7}$ & $2-7$ & 22 \\
$x_{8}$ & $3-5$ & 6 \\
$x_{9}$ & $4-5$ & 16 \\
$x_{10}$ & $4-7$ & 23 \\
\hline
\end{tabular}




\begin{tabular}{ccc}
\hline$x_{11}$ & $5-6$ & 20 \\
$x_{12}$ & $5-7$ & 17 \\
\hline \multicolumn{3}{c}{ Source: Research processing results, 2020}
\end{tabular}

2. Stage 2 : The Development of Model

Table 13. on top of the created graph model that contains the side, the point and the distance. Obtained a graph such as in Figure 2.

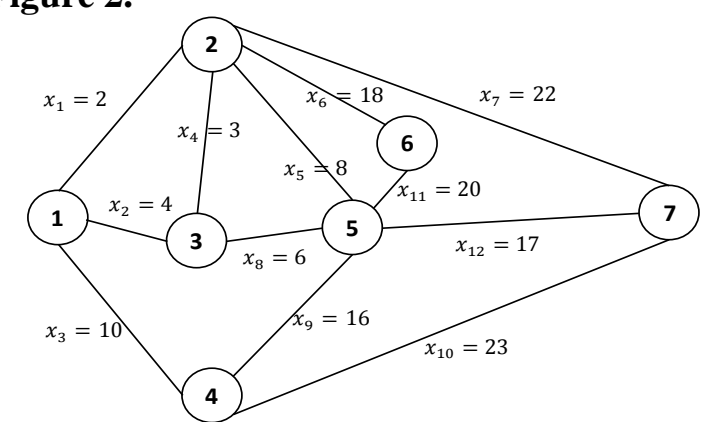

Figure 2. Graph of tissue distribution of tempe

Source: Research processing results, 2020

Based on the graph above can be solved by the method of algorithm prim. Where on the algorithm of prim the initial step is to choose one point randomly which will be used as root. After a root is elected, then select the next node that is associated with the root that has the distance or the value of the edge is smallest.

3. Stage 3 : Solving the Model

To resolve the problem of distribution, in order to obtain a settlement that can optimally use the following steps:

a. Iteration 1 select a node, for example node 1. As in Figure 3.

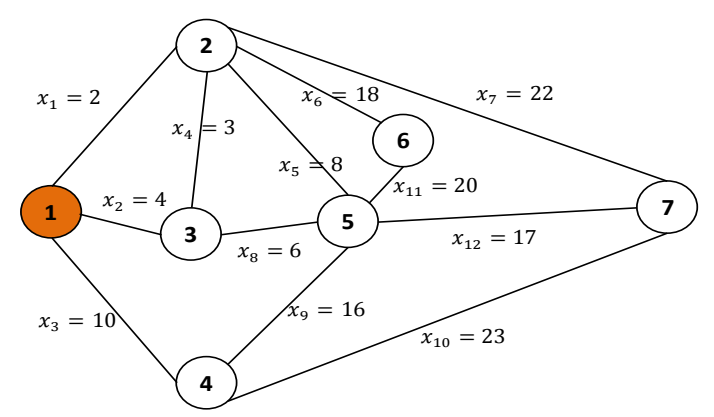

Figure 3. Graf iteration 1

Source: Research processing results, 2020

b. Iteration 2 select the side with the smallest weight associated with the point 1 , namely $\mathrm{x} 1=1-2$ with a weight of 2. As in Figure 4.

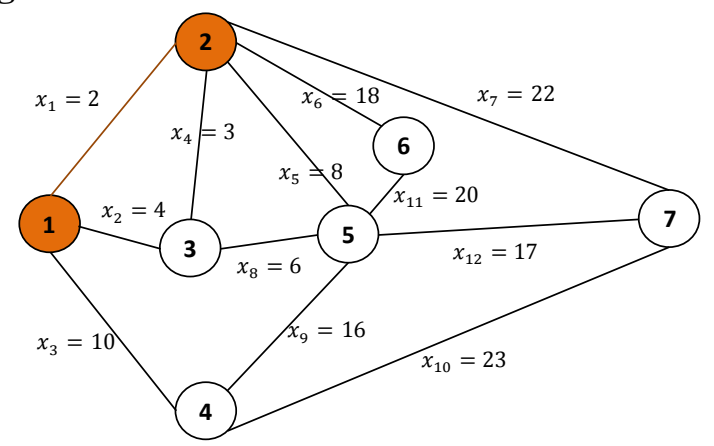

Figure 4. Graf Iteration 2

Source: Research processing results, 2020 
c. Iteration 3 select the side with the smallest weight associated with point 1 and 2 , namely $x 4=2-3$ with 3 weights. As in Figure 5.

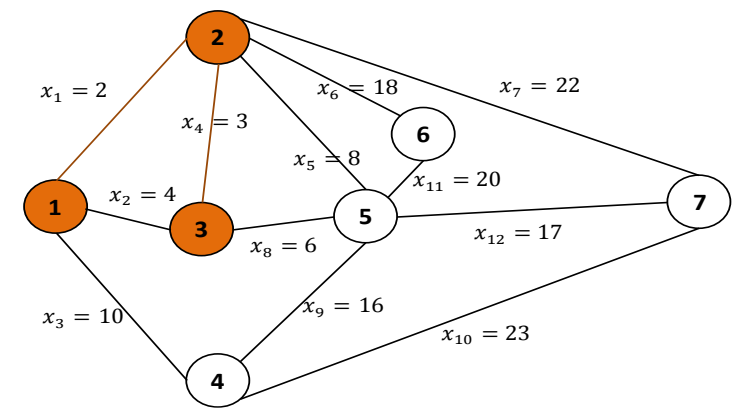

Figure 5. Graf iteration 3

Source: Research processing results, 2020

d. Iteration 4 select the side with the smallest weight associated with the point 1,2 and 3 , namely $x 8=$ $3-5$ with the weight 6 . As in Figure 6.

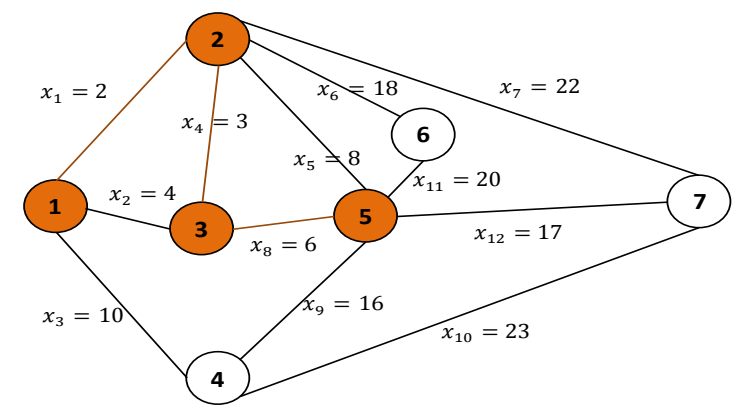

Figure 6. Graf iteration 4

Source: Research processing results, 2020

e. Iteration 5 select the side with the smallest weight associated with the point 1, 2, 3 and 4, namely $\mathrm{x} 3=1-4$ with weight 10. As in Figure 7.

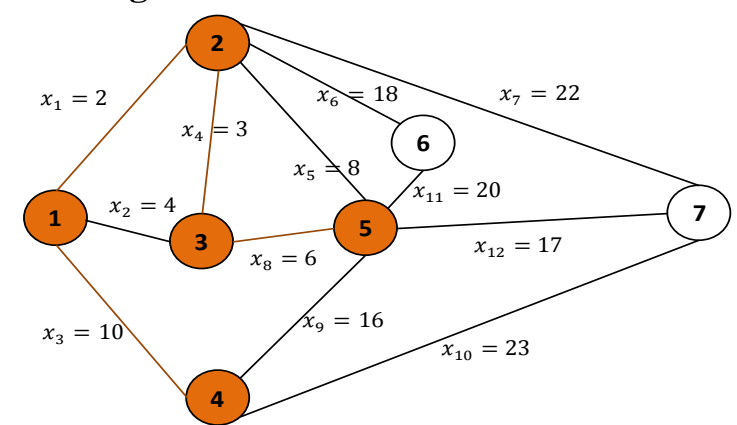

Figure 7. Graf iteration 5

Source: Research processing results, 2020

f. Iteration 6 select the side with the smallest weight associated with the point 1, 2, 3, 4 and 5, namely $\mathrm{x} 12=\mathrm{EG}$ with a weight of 17. As in Figure 8. 


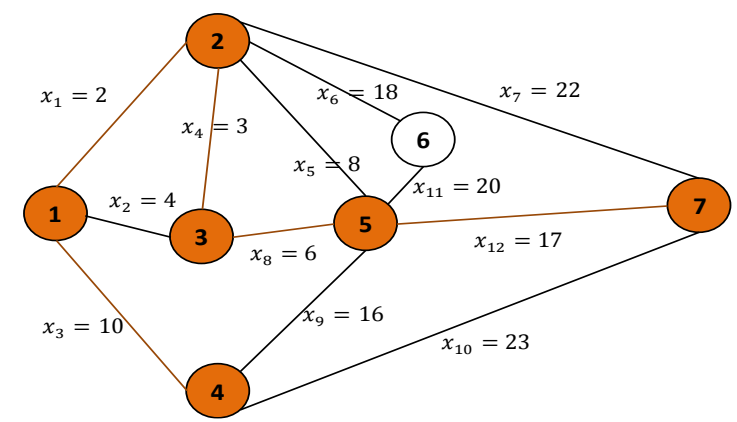

Figure 8. Graf iteration 6

Source: Research processing results, 2020

g. Iteration 7 select the side with the smallest weight associated with the point 1, 2, 3, 4, 5 and 7 , namely x6 $=2-6$ with a weight of 18 . As in Figure 9.

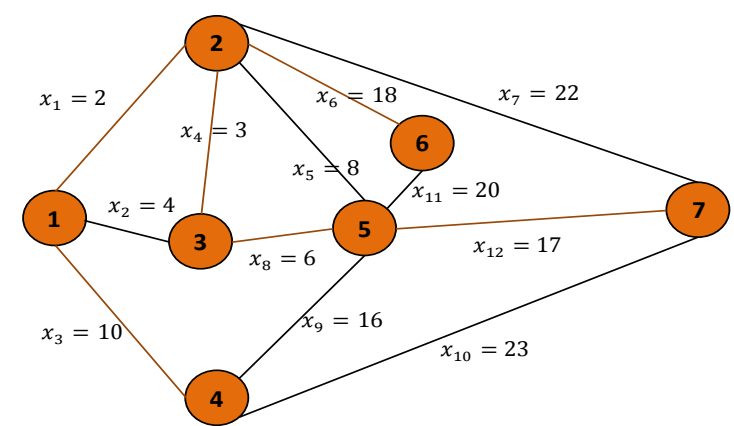

Figure 9. Graf iteration 7

Source: Research processing results, 2020

Because all nodes are already connected, then the process is stopped. So the distribution network is obtained as in Figure 10.

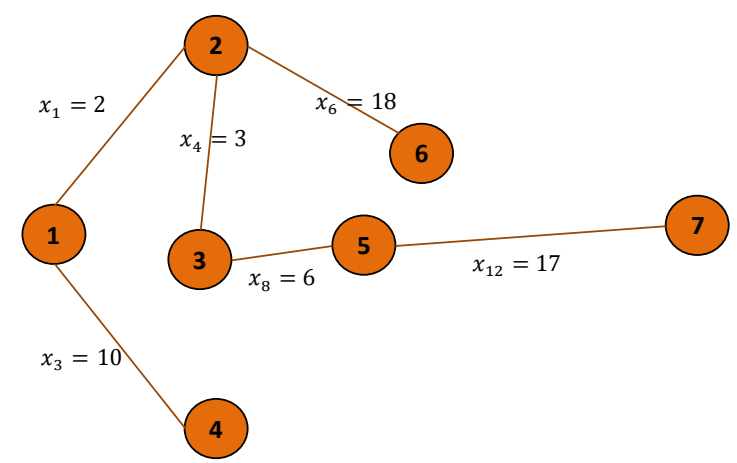

Figure 10. The results of the graph the optimal

Source: Research processing results, 2020

4. Stage 4 : Testing the Validity of the Model

From the results of the iteration end of the using methods of algorithm prim then all the dots have been connected. Based on the calculation of the algorithm prim in the previous stage. It is obtained from the tree by the amount of weight as follows:

$=(1-2)+(1-4)+(2-3)+(2-6)+(3-5)+(5-7)$

$=x_{1}+x_{3}+x_{4}+x_{6}+x_{8}+x_{12}$

$=2+10+23+18+6+17$

$=76 \mathrm{~km}$

5. Stage 5 : The Implementation of the Final Result

By the method of minimum spanning tree algorithm prim achieved a mileage of optima of each objective distribution of tempe. With the results of the distance home industry tempe - johar market at 
$2 \mathrm{~km}$, distance home industry tempe - telagasari market by $10 \mathrm{~km}$, the distance of johar market in baru karawang market at $3 \mathrm{~km}$, distance johar market - kaligandu market by $18 \mathrm{~km}$, distance to market baru karawang - bojong market by $6 \mathrm{~km}$ and the distance of the bojong market - rengasdengklok market of $17 \mathrm{~km}$.

\section{The results of Processing with the Help of the Software POM-QM for Windows}

The following results are obtained with the help of the software POM-QM for windows for both the methods are used as follows:

1. The obtained results and the optimal cost of the method of assignment (hungarian) with the help of the software POM-QM for windows. As in Figure 11.

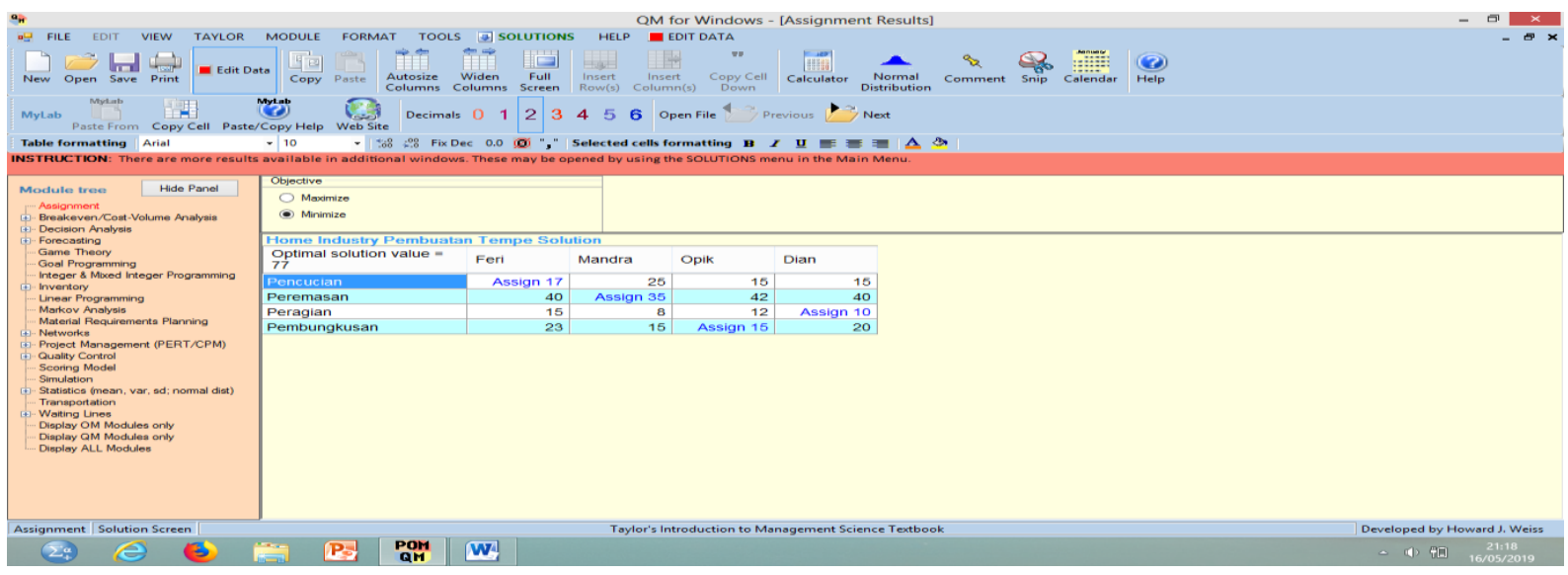

Figure 11. The results of the method of assignment (Hungarian) with the help of the software POM-QM for Windows

Source: Research processing results, 2020

2. The results obtained and the distribution of the optimum of the method of networking (minimum spanning tree) with the help of the software POM-QM for windows. As in Figure 12.

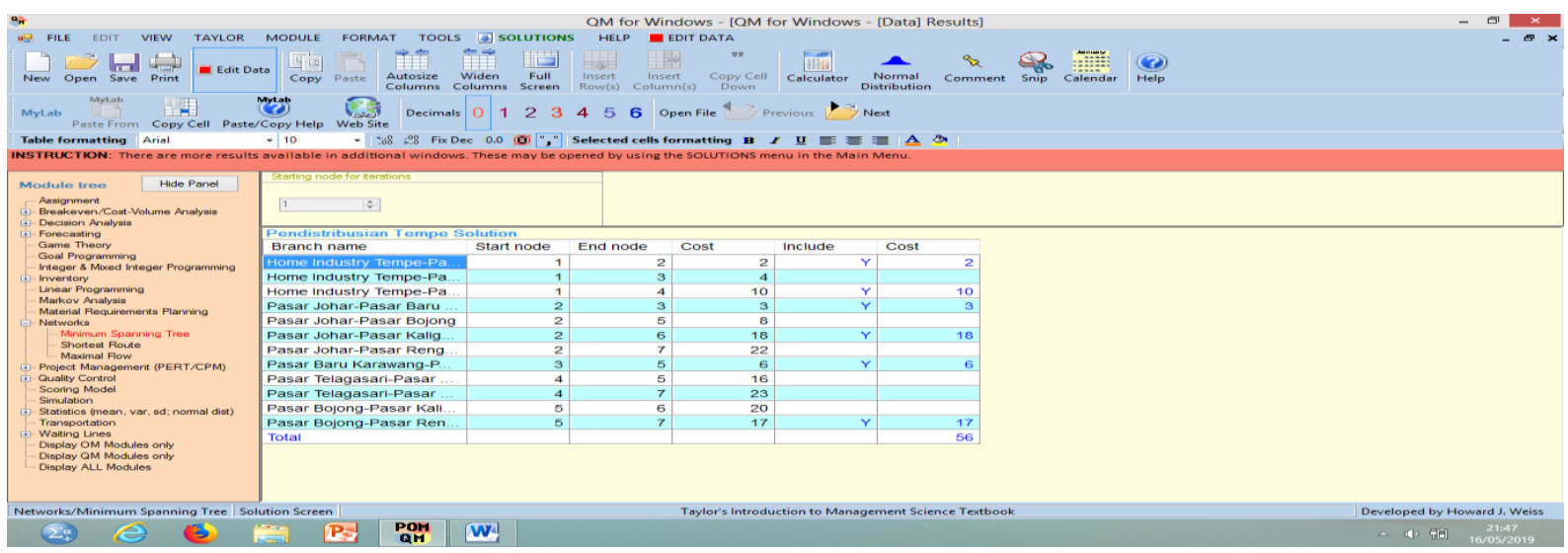

Figure 12. The results of the methods of networking (minimum spanning tree) with the help of the software POM-QM for Windows

Source: Research processing results, 2020

\section{Conclusion}

The assignment can be performed by home industry producing tempe using the method of assignment (Hungarian). The results obtained is revealed as follow: employee 1 with type of assignment laundering with a time of 17 minutes, clerk 2 with the type of assignment kneading with a time of 35 minutes, clerk 3 with the type of the assignment of wrapping with a time of 10 minutes and the employee 4 with the type of assignment brewing with a time of 15 minutes. While the distribution of tempe by using the method of networking (minimum spanning tree), obtained the shortest path in the network with distance of $76 \mathrm{~km}$. While the use of the software POM-QM for windows aims to make it easier to resolve 
the issue of the assignment of the employee with the assignment. In addition, the results obtained distribution of tempe to the destination point with the shortest distance. Then it produces the same solution with the manual processing of the previous. It is suggested that other methods related to problem assignment and networking can be applied in the following research to both of the above methods. For this reason, the implementation of assignment and hungarian method is expected to make the result of data processin in the research to be optimal.

\section{Acknowledgment}

My special gratitude goes to Rector, Dean, Study Programme Coordinators of University of Singaperbangsa Karawang, as well as Home Industry Tempe Karawang who have provided support and assistance in the research.

\section{References}

[1] H. Sarjono, Aplikasi Riset Operasi, 1st ed., Jakarta: Salemba, 2010.

[2] A. Wijaya, Pengantar Riset Operasi, 1st ed., Jakarta: Mitra Wacana Media, 2004.

[3] B. A. Noer, Belajar Mudah Riset Operasional, 1st ed., Yogyakarta: Andi, 2010.

[4] L. R. A. R., Riset Operasi, 1st ed., Bogor: In Media, 2016.

[5] S. Mulyono, Riset Operasi, 1st ed., Jakarta: Mitra Wacana Media, 2017.

[6] A. D. Saputra, Riset Operasi "Pendekatan Praktis", 1st ed., Yogyakarta: Deepublish, 2017.

[7] B. Sinring and H. Hafied, Riset Operasi (Operational Research), 1st ed., Makassar: Kretakupa Print, 2012.

[8] D. Rahmalia and T. Herlambang, Riset Operasi dan Komputasi, 1st ed., Surabaya: Kresna Bina Insan Prima, 2020.

[9] B. Soedijono, Riset Operasi II, 1st ed., Tangerang Selatan: Universitas Terbuka, 2013.

[10] J. J. Siang, Riset Operasi dalam Pendekatan Algoritmis, 1st ed., Yogyakarta: Andi, 2014.

[11] M. Yulistiana, D. Chaerani and E. Lesmana, "Penerapan Metode Hungarian dalam Penentuan Penjadwalan Matakuliah Optimal (Studi Kasus: Departemen Matematika Universitas Padjadjaran Semester Ganjil 2013-2014)," Jurnal Matematika Integratif, vol. XI, no. 1, pp. 45-64, 2015.

[12] H. J. Weiss, POM - QM for Windows Version 3, 1st ed., New Jersey: Pearson Education Inc., 2013.

[13] D. T. Pratama and H. S. Kurniawan, "Optimasi Masalah Penugasan Menggunakan Metode Hungarian untuk Meminimalkan Waktu Produksi," Bulletin of Applied Industrial Engineering Theory, vol. I, no. 1, pp. 16-20, 2020.

[14] Amalia and A. Lailasari, "Perbedaan Metode Penugasan Tim dan Penugasan Fungsional Pemberian Asuhan Keperawatan," Babul Ilmi_Jurnal Ilmiah Multi Science Kesehatan, vol. XII, no. 1, pp. 119127, 2020.

[15] D. M. Vidhiasi, "Google Classroom for English Conversation AT Akademi Maritim Nusantara Cilacap," Jurnal Saintara, vol. IV, no. 2, pp. 1-4, 2020.

[16] D. D. Tamimi, I. Purnamasari and Wasono, "Proses Optimasi Masalah Penugasan One-Objective dan Two-Objective Menggunakan Metode Hungarian (Studi Kasus: Usaha Kerajinan Rotan Toko Rotan Sejati Samarinda pada Bulan November sampai dengan Desember 2016)," Jurnal Eksponensial, vol. VIII, no. 1, pp. 71-80, 2017.

[17] S. Basuki, "Model Penugasan Belajar di Rumah yang Menyenangkan bagi Siswa di Masa Pandemi Covid 19," Jurnal Pendidikan Dasar Nusantara, vol. VI, no. 1, pp. 199-210, 2020.

[18] G. N. P. Suwandira, R. Indryani and I. A. R. Widhiawati, "Optimasi Biaya Pekerjaa Aspal Hot Mix dengan Model Penugasan (Assignment Model) pada Proyek Jalan di Bali," Jurnal Ilmiah Teknik Sipil, vol. X, no. 1, pp. 12-18, 2006.

[19] Sutejo, "Model Assignment Pembelajaran Ekonomi Berbasiskan Konstruktivistik," Jurnal Pengembangan Pendidikan, vol. III, no. 1, pp. 74-81, 2006.

[20] Y. A. Putri, Z. F. Hunusalela and E. Wiratmani, "Usulan Penugasan dengan Metode Hungarian sebagai Alat Meningkatkan Efisiensi di Bagian Finishing (Studi Kasus di PT Duaroda Saranatama)," JITMI, vol. II, no. 2, pp. 131-137, 2019. 
[21] E. Nugraha and R. M. Sari, "Efektivitas Biaya Pengiriman pada Perusahaan Roti dengan Menggunakan Metode Transportasi," Journal Competitive, vol. XIV, no. 2, pp. 21-26, 2019.

[22] H. Sitorus, R. Suminar and A. D. Santoso, "Optimasi Target Produksi Berbiaya Alokasi Pekerjaan Minimum dengan Pendekatan Program Linier (Studi Kasus : PT. Tass Engineering)," Jurnal Kajian Teknik Mesin, vol. IV, no. 2, pp. 81-93, 2019. 